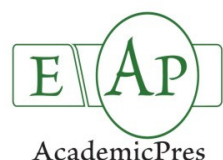

AcademicPres

\title{
Effects of Various Mixed Salt-Alkaline Stress Conditions on Seed Germination and Early Seedling Growth of Leymus chinensis from Songnen Grassland of China
}

\author{
Jixiang LIN ${ }^{1}$, Zhuolin $\mathrm{LI}^{2}$, Shuai SHAO${ }^{1}$, Yingnan WANG ${ }^{1}$, Chunsheng $\mathrm{MU}^{2 *}$ \\ ${ }^{1}$ Alkali Soil Natural Environmental Science Center, Northeast Forestry University/Key Laboratory of Saline-alkali Vegetation Ecology \\ Restoration in Oil Field, Ministry of Education, Harbin, 150040, China; jixiang851012@gmail.com \\ ${ }^{2}$ Key Laboratory of Vegetation Ecology of Ministry of Education, Institute of Grassland Science, Northeast Normal University, Changchun, \\ 130024, China; mucs821@gmail.com (*orresponding author)
}

\begin{abstract}
Soil salinization and alkalization always co-occur in grassland ecosystem, but little information exists concerning the mixed effects of salt-alkaline stresses on plants. Leymus chinensis is considered as one of the most promising grass species in Songnen Grassland of Northern China. In this study, we investigated the effects of 30 mixed salt-alkaline conditions $\left(\mathrm{NaCl}_{2} \mathrm{Na}_{2} \mathrm{SO}_{4}\right.$, $\mathrm{NaHCO}_{3}$ and $\mathrm{Na}_{2} \mathrm{CO}_{3} ; \mathrm{pH} 7.10-10.18$ and salinity $50-250 \mathrm{mM}$ ) on seed germination and seedling growth of $L$. chinensis. The results showed that germination percentage and rate were both decreased with increasing salinity and $\mathrm{pH}$. Nongerminated seeds germinated well after being transferred to distilled water from treatment groups. Shoot and radicle growth were also affacted by salinity, $\mathrm{pH}$ and their interactions. However, radicle length decreased more markedly with increasing salinity and $\mathrm{pH}$, and was strongly inhibited when $\mathrm{pH}$ reached 8.05. Stepwise regression analysis results showed that salinity was the dominant factor for seed germination under mixed salt-alkaline stress conditions. However, once radicle break through the seed coat, and $\mathrm{pH}$ changed into the dominant factor for seedling establishment. These results indicated that mixed salt-alkaline stresses had different impacts on germination and early seedling stages of L. chinensis. A better understanding of the germination and seedling processes should facilitate the effective utilization of this species under such complex environment.
\end{abstract}

Keywords: salt-alkaline stresses, seed germination, germination recovery, shoot and radicle growth

\section{Introduction}

Soil salinization and alkalization is a major environmental problem throughout the world, which not only limits growth and production of plant but also results in land degradation. For example, arable land acreage of the world is $1.5 \times 10^{9}$ ha, but $23 \%\left(0.34 \times 10^{9}\right.$ ha $)$ of the area is saline, and $37 \%\left(0.56 \times 10^{9} \mathrm{ha}\right)$ is sodic. In Songnen Plains of Northeast China, approximately $70 \%$ of the natural grassland has been seriously degraded due to the impacts of salt and alkali soils, and this trend is still increasing (Zhang and $\mathrm{Mu}, 2009$ ).

In most salt-alkaline soil of Northeast China, the main harmful salts are $\mathrm{NaCl}, \mathrm{Na}_{2} \mathrm{SO}_{4}, \mathrm{NaHCO}_{3}$ and $\mathrm{Na}_{2} \mathrm{CO}_{3}$, coming from neutral salts and alkaline salts (Yang et al., 2008). Previous studies have proved that alkaline salt stress and neutral salt stress are differed greatly, and should be called alkali stress and salt stress, respectively (Shi and Yin, 1993). The deleterious effects of alkaline stress are more severe than salt stress (Yang et al., 2008; Zhang and Mu, 2009; Guo et al., 2009). In general, the impact of salt stress involves osmotic and ionic effects, alkali stress has same stress factors but added the influence of high $\mathrm{pH}$, which can inhibit ion uptake and disrupt ionic balance of plant cells (Munns, 2002; Yang et al., 2007). However, salinization and alkalization always co-occur in nature conditions, plant survive under salt and alkaline stresses are very complex (Shi and Wang, 2005; Li et al., 2009). Therefore, mixed effect of salt stress and alkali stress should be further explored, not only that of salt stress or alkali stress.

Seed germination and seedling establishment are the most crucial stages for plant survival under saline-alkaline environment ( $\mathrm{Qu}$ et al., 2008). Seed germination can determine where and when seedling growth starts (Lin et al., 2011). High salinities in the soil always result in both a delay and reduction of seed germination. It can also cause a complete inhibition of germination if salinity concentration is high enough. However, due to climatic factors such as rainfall or melted snow, salinity concentration in the soil always decreases, and thus provides a suitable condition to seed for germination. Consequently, most halophytes seeds remain viable at high salinity and germinate again until salinity concentration decreases (Ungar, 1991).

Leymus chinensis (Trin.) Tzvel. is a perennial rhizomatous forage grass of the family Poaceae. It is widely 
distributed in the eastern region of the Eurasian steppes, the Northern and Eastern parts of the People's Republic of Mongolia, the Northeastern China Plain, and the Inner Mongolia Plateau of China (Wang et al., 2004). This plant is rich in proteins, carbohydrates, minerals and is also highly tolerant to saline-alkaline soils (Huang et al., 2002). Due to its economic values and tolerant traits towards salinealkaline stress, Leymus chinensis is considered as one of the most promising grass species for grassland rehabilitation and restoration in Northern China (Liu and Qi, 2004). However, to our knowledge, few studies focus on this species response to mixed salt-alkaline stresses especially for seed germination and early seedling stage. In this paper, mixtures of four salts $\mathrm{NaCl}, \mathrm{Na}_{2} \mathrm{SO}_{4}, \mathrm{NaHCO}_{3}$ and $\mathrm{Na}_{2} \mathrm{CO}_{3}$ were used in various proportions to simulate 30 treatments of mixed salt-alkaline conditions. The aims were (1) to test the effects of mixed salt-alkaline stresses on seed germination and early seedling growth of $L$. chinensis, (2) to analyze the key factor among all the stress factors for the two stages.

\section{Materials and methods}

\section{Plant material}

Mature seeds (Thousand-seed weight is $2.4 \mathrm{~g}$ ) of $L$. chinensis were collected from the Grassland Ecosystem Field Station, Institute of Grassland Science, Jilin province, China $\left(123^{\circ} 44^{\prime} \mathrm{E}, 44^{\circ} 44^{\prime} \mathrm{N}\right)$. This area is characterized by a semiarid, continental monsoonal climate. Mean annual precipitation and temperature are $300-450 \mathrm{~mm}$, and from 4.6 to $6.4^{\circ} \mathrm{C}$. The soil type is mixed salt-alkali meadow soil (Zhang et al., 2009). Seeds were then stored in paper bags at $4^{\circ} \mathrm{C}$ until further use.

\section{Mixed salt-alkaline stress conditions}

To simulate mixed salt-alkali conditions, two neutral salts $\left(\mathrm{NaCl}\right.$ and $\left.\mathrm{Na}_{2} \mathrm{SO}_{4}\right)$ and two alkaline salts $\left(\mathrm{NaHCO}_{3}\right.$ and $\mathrm{Na}_{2} \mathrm{CO}_{3}$ ) were chose according to the salt composition of the salt-alkaline soil in Northeast China (Peng et al., 2008). Four salts were mixed in various proportions based on the tolerance of salt-alkaline stress and the salinity and $\mathrm{pH}$ in Songnen Grassland. Six treatment groups (A-F) were set with increasing alkalinity. Salt composition and molar ratio of various treatments were shown in Tab. 1. Within each group, five concentrations were used $(50,100,150,200$ and $250 \mathrm{mM})$. Total 30 mixed stress treatments $\left(\mathrm{A}_{1}-\mathrm{F}_{5}, \mathrm{pH}\right.$ 7.10-10.18, and salinity 50-250 mM) were shown in Tab. 2.

Tab. 1. Salt composition and molar ratio of various treatments

\begin{tabular}{ccccc}
\hline \multicolumn{5}{c}{ Salt composition and molar proportions } \\
\hline Treatments & $\mathrm{NaCl}$ & $\mathrm{Na}_{2} \mathrm{SO}_{4}$ & $\mathrm{NaHCO}_{3}$ & $\mathrm{Na}_{2} \mathrm{CO}_{3}$ \\
\hline $\mathrm{A}$ & 2 & 1 & 0 & 0 \\
$\mathrm{~B}$ & 1 & 1 & 1 & 0 \\
$\mathrm{C}$ & 12 & 9 & 8 & 1 \\
$\mathrm{D}$ & 8 & 9 & 12 & 1 \\
$\mathrm{E}$ & 12 & 1 & 8 & 9 \\
F & 0 & 0 & 2 & 1 \\
\hline
\end{tabular}

Tab. 2. Stress factors of various treatments

\begin{tabular}{|c|c|c|c|c|c|c|c|}
\hline \multirow{2}{*}{ Treatment } & \multicolumn{7}{|c|}{ Stress factors } \\
\hline & $\mathrm{pH}$ value & Salinity $(\mathrm{mM})$ & $\mathrm{Na}^{+}(\mathrm{mM})$ & $\mathrm{Cl}^{-}(\mathrm{mM})$ & $\mathrm{SO}_{4}^{2-}(\mathrm{mM})$ & $\mathrm{HCO}_{3}{ }^{-}(\mathrm{mM})$ & $\mathrm{CO}_{3}{ }^{2-}(\mathrm{mM})$ \\
\hline$A_{1}$ & 7.10 & 50 & 66.7 & 33.3 & 16.7 & 0.0 & 0.0 \\
\hline $\mathrm{A}_{2}$ & 7.14 & 100 & 133.4 & 66.6 & 33.4 & 0.0 & 0.0 \\
\hline $\mathrm{A}_{3}$ & 7.20 & 150 & 200 & 100 & 50 & 0.0 & 0.0 \\
\hline $\mathrm{A}_{4}$ & 7.24 & 200 & 266.8 & 133.2 & 66.8 & 0.0 & 0.0 \\
\hline $\mathrm{A}_{5}$ & 7.28 & 250 & 333.5 & 166.5 & 83.5 & 0.0 & 0.0 \\
\hline $\mathrm{B}_{1}$ & 7.80 & 50 & 66.7 & 16.7 & 16.7 & 16.7 & 0.0 \\
\hline $\mathrm{B}_{2}$ & 8.05 & 100 & 133.4 & 33.4 & 33.4 & 33.4 & 0.0 \\
\hline $\mathrm{B}_{3}$ & 8.22 & 150 & 200 & 50 & 50 & 50 & 0.0 \\
\hline $\mathrm{B}_{4}$ & 8.28 & 200 & 266.8 & 66.8 & 66.8 & 66.8 & 0.0 \\
\hline $\mathrm{B}_{5}$ & 8.35 & 250 & 333.5 & 83.5 & 83.5 & 83.5 & 0.0 \\
\hline $\mathrm{C}_{1}$ & 8.90 & 50 & 66.7 & 20 & 15 & 13.3 & 1.7 \\
\hline $\mathrm{C}_{2}$ & 8.92 & 100 & 133.4 & 40 & 30 & 26.6 & 3.4 \\
\hline $\mathrm{C}_{3}$ & 8.96 & 150 & 200 & 60 & 45 & 39.9 & 5.1 \\
\hline $\mathrm{C}_{4}$ & 8.98 & 200 & 266.8 & 80 & 60 & 53.2 & 6.8 \\
\hline $\mathrm{C}_{5}$ & 9.02 & 250 & 333.5 & 100 & 75 & 66.5 & 8.5 \\
\hline $\mathrm{D}_{1}$ & 9.05 & 50 & 66.7 & 13.3 & 15 & 20 & 1.7 \\
\hline $\mathrm{D}_{2}$ & 9.10 & 100 & 133.4 & 26.6 & 30 & 40 & 3.4 \\
\hline $\mathrm{D}_{3}$ & 9.15 & 150 & 200 & 39.9 & 45 & 60 & 5.1 \\
\hline $\mathrm{D}_{4}$ & 9.18 & 200 & 266.8 & 53.2 & 60 & 80 & 6.8 \\
\hline $\mathrm{D}_{5}$ & 9.24 & 250 & 333.5 & 66.5 & 75 & 100 & 8.5 \\
\hline $\mathrm{E}_{1}$ & 9.56 & 50 & 66.7 & 20 & 1.7 & 13.3 & 15 \\
\hline$E_{2}$ & 9.60 & 100 & 133.4 & 40 & 3.4 & 26.6 & 30 \\
\hline$E_{3}$ & 9.64 & 150 & 200 & 60 & 5.1 & 39.9 & 45 \\
\hline $\mathrm{E}_{4}$ & 9.69 & 200 & 266.8 & 80 & 6.8 & 53.2 & 60 \\
\hline $\mathrm{E}_{5}$ & 9.76 & 250 & 333.5 & 100 & 8.5 & 66.5 & 75 \\
\hline $\mathrm{F}_{1}$ & 9.90 & 50 & 66.7 & 0.0 & 0.0 & 33.3 & 16.7 \\
\hline $\mathrm{F}_{2}$ & 9.94 & 100 & 133.4 & 0.0 & 0.0 & 66.6 & 33.4 \\
\hline $\mathrm{F}_{3}$ & 9.98 & 150 & 200 & 0.0 & 0.0 & 100 & 50 \\
\hline $\mathrm{F}_{4}$ & 10.12 & 200 & 266.8 & 0.0 & 0.0 & 133.2 & 66.8 \\
\hline $\mathrm{F}_{5}$ & 10.18 & 250 & 333.5 & 0.0 & 0.0 & 166.5 & 83.5 \\
\hline
\end{tabular}


156

\section{Seed germination test}

Seeds were surface sterilized in $0.1 \%$ mercury chloride for $10 \mathrm{~min}$, and then washed with distilled water and airdried to avoid fungus attack before being used in our experiments.

Seeds were placed in $11 \mathrm{~cm}$ Petri dishes on two layers of $12.5 \mathrm{~cm}$ filter paper moistened with $10 \mathrm{~mL}$ of the treatment solutions. Four replicates of 50 seeds were used for each treatment and distilled water was used as a control. The Petri dishes were placed in growth chambers and maintained at $30 / 20{ }^{\circ} \mathrm{C}$ with $12 \mathrm{~h}$ photoperiod (Sylvania cool white fluorescent lamps, $200 \mathrm{umolm}^{-2} \mathrm{~s}^{-1}, 400-700 \mathrm{~nm}$, HPG-400, Haerbin, China). Seeds were considered germinated with the emergence of the radicel. Germination percentage was recorded every 2 days for $20 \mathrm{~d}$. Nongerminated seeds from all the treatments were then transferred to distilled water to study the recovery of germination, which was also recorded at $2 \mathrm{~d}$ intervals for 20 d.

Germination rate was estimated by using a modified Timson index of germination velocity, $\Sigma \mathrm{G} / \mathrm{t}$, where $G$ is the percentage of seed germination and $t$ is the germination time (Lin et al., 2011). The maximum value with our data was 50 (i.e.1000/20). The recovery percentage was calculated according to the number of germinated seeds after being transferred to distilled water divided by the number of nongerminated seeds under saline and alkaline stresses.

\section{Seedling growth test}

For evaluation of the effects of mixed salt-alkaline stresses on early seedling growth, seeds were incubated initially in distilled water at $30 / 20{ }^{\circ} \mathrm{C}$ with $12 \mathrm{~h}$ photoperiod, when the coleoptile had just emerged, 20 of the early seedlings were then incubated with treatment solutions. Early seedling growth was ended after $15 \mathrm{~d}$, and shoot lengths and radicle lengths were recorded.

\section{Data analysis}

All data were analyzed using SPSS 13.0 (SPSS Inc, Chicago, IL, USA). Tukey's tests were performed for multiple comparisons to determine significant $(p<0.05)$ differences between individual treatments. A two-way ANOVA was used to test the effects of the factors $(\mathrm{pH}$ and salinity) and their interactions on seed germination and seedling growth. The data were expressed as mean \pm S.E. Stepwise regression analysis was performed for the key factor.

\section{Results}

Germination of $L$. chinensis seeds was significantly affected by $\mathrm{pH}$, salinity and their interactions of the two factors $(\mathrm{p}<0.001, T a b .3)$. Maximum seed germination percentage was obtained in distilled water, and seed reached the highest final percentage of $72.5 \%$ under this condition. Germination decreased with increasing salinity under all treatment groups, and sharply decreased in group $\mathrm{E}$ and $\mathrm{F}$ (Fig.1, Tab. 4). At highest salt concentration $(250 \mathrm{mM})$, germination percentage in group A was $6.5 \%$, while seeds showed no capacity for germination in the other five treatment groups (B-F). In group $\mathrm{F}$ (highest $\mathrm{pH} /$ alkalinity), seed could not germinate when salinity was only $150 \mathrm{mM}$. However, in the other five treatment groups (A-E),
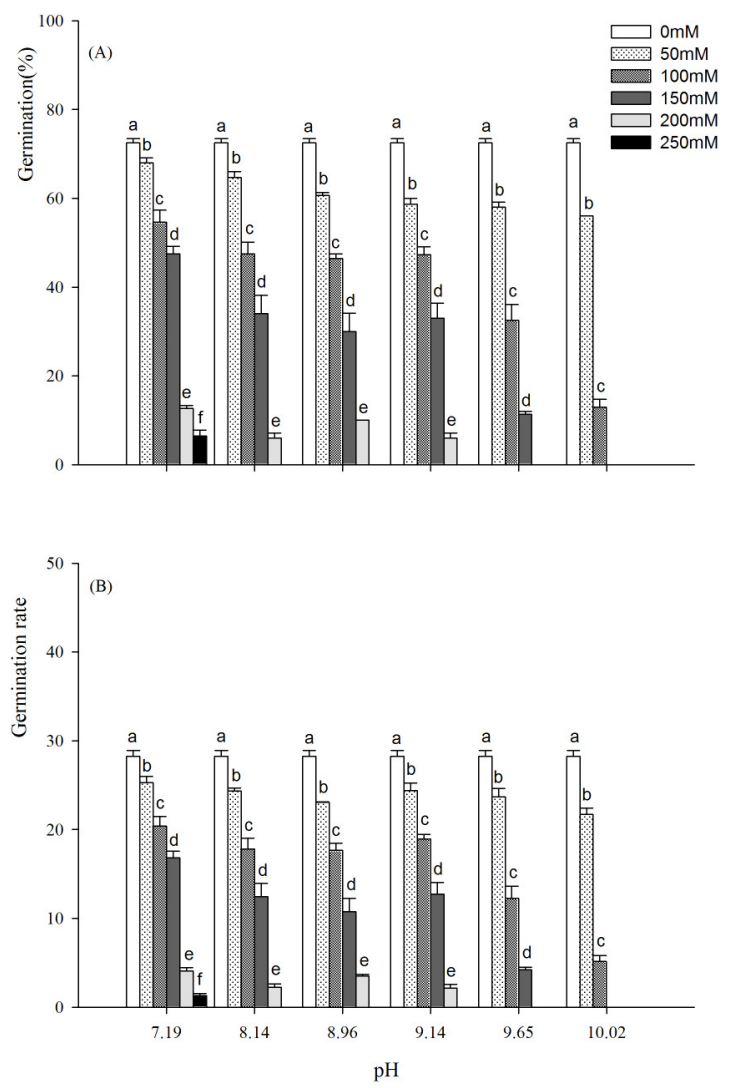

Fig. 1. Germination (A), germination rate (B) of Leymus chinensis in each treatment. The values are the means of four replicates. Means followed by different letters are significantly different at $\mathrm{p}<0.05$ according to a least significant difference test

Tab. 3. Two-way ANOVA of effects of salinity, $\mathrm{pH}$ and their interactions on seed germination and seedling growth of $L$. chinensis

\begin{tabular}{|c|c|c|c|c|c|}
\hline Source of variance & Germination (\%) & Germination rate & Recovery percentage (\%) & Shoot length $(\mathrm{cm})$ & Root length $(\mathrm{cm})$ \\
\hline Salinity & $1898.4^{* * *}$ & $1614.7^{* * *}$ & $104.6^{* * *}$ & $239.92^{* * *}$ & $637.48^{* * *}$ \\
\hline $\mathrm{pH}$ & $113.5^{* * *}$ & $59.7^{* * *}$ & $137.9^{* * *}$ & $72.08^{* * *}$ & $589.48^{* * *}$ \\
\hline Salinity $\times \mathrm{pH}$ & $22.6^{* * *}$ & $16.8^{* * *}$ & $14.5^{* * *}$ & $5.54^{* * *}$ & $76.70^{* * *}$ \\
\hline
\end{tabular}

Data represent $F$-values at 0.05 level. ${ }^{* * *} \mathrm{p}<0.001$ 
Tab. 4. Seed germination situations under various treatments

\begin{tabular}{|c|c|c|c|c|}
\hline \multirow{2}{*}{ Treatment/Average $\mathrm{pH}$} & \multirow{2}{*}{ Salinity $(\mathrm{mM})$} & \multicolumn{3}{|c|}{ Seed germination (\%, mean \pm s.e., $n=4$ ) } \\
\hline & & Initial germination (\%) & Recovery percentage(\%) & Total germination (\%) \\
\hline Control & 0 & $72.5 \pm 1.0^{\mathrm{a}}$ & $0.0 \pm 0.0$ & $72.5 \pm 1.0^{\mathrm{a}}$ \\
\hline \multirow[t]{5}{*}{$\mathrm{A} / \mathrm{pH}=7.19$} & 50 & $68.0 \pm 1.2^{\mathrm{b}}$ & $4.9 \pm 0.6^{\mathrm{a}}$ & $69.6 \pm 0.8^{a}$ \\
\hline & 100 & $54.7 \pm 2.7^{c}$ & $11.3 \pm 0.7^{\mathrm{b}}$ & $59.9 \pm 2.0^{\mathrm{b}}$ \\
\hline & 150 & $47.5 \pm 1.7^{\mathrm{d}}$ & $19.0 \pm 1.0^{\mathrm{c}}$ & $56.7 \pm 0.7^{b}$ \\
\hline & 200 & $12.7 \pm 0.7^{\mathrm{e}}$ & $22.8 \pm 0.8^{\mathrm{d}}$ & $32.7 \pm 0.7^{\mathrm{c}}$ \\
\hline & 250 & $6.5 \pm 1.3^{f}$ & $32.8 \pm 1.3^{\mathrm{e}}$ & $36.0 \pm 1.2^{\mathrm{c}}$ \\
\hline \multirow[t]{5}{*}{$\mathrm{B} / \mathrm{pH}=8.14$} & 50 & $64.7 \pm 1.3^{\mathrm{b}}$ & $5.0 \pm 0.6^{\mathrm{a}}$ & $67.5 \pm 2.3^{a}$ \\
\hline & 100 & $47.5 \pm 2.6^{c}$ & $18.3 \pm 1.6^{\mathrm{b}}$ & $58.3 \pm 2.4^{\mathrm{b}}$ \\
\hline & 150 & $34.0 \pm 4.2^{\mathrm{d}}$ & $37.0 \pm 1.3^{c}$ & $58.0 \pm 2.0^{\mathrm{b}}$ \\
\hline & 200 & $6.0 \pm 1.2^{\mathrm{e}}$ & $37.7 \pm 1.1^{\mathrm{c}}$ & $42.4 \pm 1.6^{\mathrm{c}}$ \\
\hline & 250 & $0.0 \pm 0.0^{\mathrm{e}}$ & $40.7 \pm 1.3^{\mathrm{c}}$ & $40.7 \pm 1.3^{\mathrm{c}}$ \\
\hline \multirow[t]{5}{*}{$\mathrm{C} / \mathrm{pH}=8.96$} & 50 & $60.7 \pm 0.7^{b}$ & $13.6 \pm 1.8^{\mathrm{a}}$ & $64.7 \pm 0.7^{b}$ \\
\hline & 100 & $46.5 \pm 1.0^{c}$ & $22.7 \pm 1.9^{b}$ & $59.3 \pm 0.7^{\mathrm{c}}$ \\
\hline & 150 & $30.0 \pm 4.2^{\mathrm{d}}$ & $35.3 \pm 0.6^{\mathrm{c}}$ & $54.7 \pm 2.9^{\mathrm{d}}$ \\
\hline & 200 & $10.0 \pm 0.0^{\mathrm{e}}$ & $29.4 \pm 1.4^{\mathrm{cd}}$ & $36.5 \pm 1.3^{\mathrm{e}}$ \\
\hline & 250 & $0.0 \pm 0.0^{f}$ & $32.7 \pm 0.7^{\mathrm{d}}$ & $32.7 \pm 0.7^{\mathrm{e}}$ \\
\hline \multirow[t]{5}{*}{$\mathrm{D} / \mathrm{pH}=9.14$} & 50 & $58.7 \pm 1.3^{b}$ & $29.0 \pm 2.0^{\mathrm{a}}$ & $70.7 \pm 0.7^{\mathrm{a}}$ \\
\hline & 100 & $47.3 \pm 1.8^{c}$ & $39.1 \pm 2.0^{\mathrm{b}}$ & $68.0 \pm 0.0^{\mathrm{ab}}$ \\
\hline & 150 & $33.0 \pm 3.4^{\mathrm{d}}$ & $43.4 \pm 3.3^{b}$ & $64.0 \pm 3.8^{\mathrm{b}}$ \\
\hline & 200 & $6.0 \pm 1.2^{\mathrm{e}}$ & $40.9 \pm 1.5^{\mathrm{b}}$ & $45.3 \pm 1.3^{c}$ \\
\hline & 250 & $0.0 \pm 0.0^{\mathrm{e}}$ & $44.5 \pm 1.5^{b}$ & $44.5 \pm 1.5^{c}$ \\
\hline \multirow[t]{5}{*}{$\mathrm{E} / \mathrm{pH}=9.65$} & 50 & $58.0 \pm 1.2^{\mathrm{b}}$ & $38.1 \pm 2.4^{\mathrm{ab}}$ & $74.0 \pm 1.2^{\mathrm{a}}$ \\
\hline & 100 & $32.5 \pm 3.6^{c}$ & $35.3 \pm 1.1^{\mathrm{a}}$ & $53.3 \pm 1.3^{\mathrm{b}}$ \\
\hline & 150 & $11.3 \pm 0.7^{\mathrm{d}}$ & $35.5 \pm 1.1^{\mathrm{a}}$ & $41.3 \pm 1.3^{\mathrm{c}}$ \\
\hline & 200 & $0.0 \pm 0.0^{\mathrm{e}}$ & $38.0 \pm 2.6^{\mathrm{ab}}$ & $38.0 \pm 2.6^{c}$ \\
\hline & 250 & $0.0 \pm 0.0^{\mathrm{e}}$ & $44.0 \pm 3.0^{\mathrm{b}}$ & $44.0 \pm 3.0^{c}$ \\
\hline \multirow[t]{5}{*}{$\mathrm{F} / \mathrm{pH}=10.02$} & 50 & $56.0 \pm 0.1^{\mathrm{b}}$ & $41.9 \pm 1.8^{\mathrm{b}}$ & $74.4 \pm 1.3^{\mathrm{a}}$ \\
\hline & 100 & $13.0 \pm 1.7^{\mathrm{c}}$ & $34.2 \pm 1.8^{\mathrm{a}}$ & $53.0 \pm 4.7^{b}$ \\
\hline & 150 & $0.0 \pm 0.0^{\mathrm{d}}$ & $32.5 \pm 1.0^{\mathrm{a}}$ & $32.5 \pm 1.0^{c}$ \\
\hline & 200 & $0.0 \pm 0.0^{\mathrm{d}}$ & $39.0 \pm 1.3^{\mathrm{b}}$ & $39.0 \pm 1.3^{\mathrm{c}}$ \\
\hline & 250 & $0.0 \pm 0.0^{\mathrm{d}}$ & $47.5 \pm 1.7^{c}$ & $47.5 \pm 1.7^{b}$ \\
\hline
\end{tabular}

Different letters indicate significant differences from different salinity concentrations $(\mathrm{p}<0.05)$

germination percentages were $47.5 \%, 34.0 \%, 30.0 \%, 33.0 \%$ and $11.3 \%$, respectively.

Germination rate was also significantly affected by $\mathrm{pH}$, salinity and their interactions $(\mathrm{p}<0.001, \mathrm{Tab} .3)$. The downtrend with increasing salinity and $\mathrm{pH}$ was similar to that of germination percentage. Germination rate in group A was higher than other groups, and group $\mathrm{E}$ and $\mathrm{F}$ had the greatest reduction, which were 4.2 and 0 at $150 \mathrm{mM}$ salinity, significantly lower than the other treatment groups $(A-D)(p<0.05)$. Once salinity concentration $\geq 200 \mathrm{mM}$, germination rate were 0 in group $\mathrm{E}$ and $\mathrm{F}$.

When nongerminated seeds were transferred from treatment solutions to distilled water, most of them germinated well. Recovery percentage was also affected by $\mathrm{pH}$, salinity and their interactions $(\mathrm{p}<0.001$, Tab. 3). Recovery percentages increased with increasing salinity in all the treatment groups, and reached highest at $250 \mathrm{mM}$ salinity (Tab. 4).

Both shoot length and radicle length were affected by $\mathrm{pH}$, salinity and their interactions $(\mathrm{p}<0.001$, Tab. 3, Fig. 2$)$. There was no shoot emerged at $250 \mathrm{mM}$ salinity in all the treatment groups, and only for $200 \mathrm{mM}$ in group E and F. Radicle length of $L$. chinensis seedlings under various mixed salt-alkaline stresses was significantly less than that of controls, especially under high $\mathrm{pH}$ groups. For example, radicle length was only $0.2 \mathrm{~cm}$ in group $\mathrm{F}$ even though salinity concentration was $50 \mathrm{mM}$.
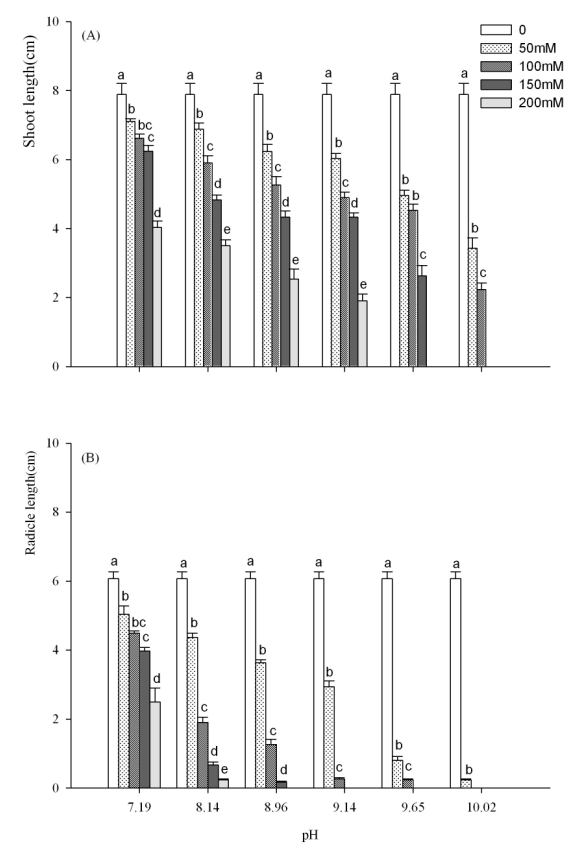

Fig. 2. Shoot length (A) and radicle length (B) of Leymus chinensis seedlings in each treatment. The values are the means of four replicates. Means followed by different letters are significantly different at $\mathrm{p}<0.05$ according to a least significant difference test 
Tab. 5. Results of stepwise regression between every index and stress factors

\begin{tabular}{|c|c|c|c|c|c|c|c|c|c|}
\hline & Model & R2 & ANOVA test & $\beta 1$ & $\beta 2$ & $\beta 3$ & $\beta 4$ & $\beta 5$ & $\beta 6$ \\
\hline Germination (\%) & $Y=137.766-0.299 X 2-7.463 X 1$ & 0.888 & $\mathrm{p}<0.001$ & -0.293 & -0.873 & & & & \\
\hline Germination rate & $Y=49.546-0.118 X 2-2.452 X 1$ & 0.889 & $\mathrm{p}<0.001$ & -0.248 & -0.887 & & & & \\
\hline Shoot length $(\mathrm{cm})$ & $Y=17.677-0.027 X 2-1.161 X 1$ & 0.862 & $\mathrm{p}<0.001$ & -0.442 & -0.776 & & & & \\
\hline Root length $(\mathrm{cm})$ & $Y=19.339-1.891 X 1-0.029 \times 5-0.011 X 4$ & 0.818 & $\mathrm{p}<0.001$ & -1.107 & & & -0.280 & -0.497 & \\
\hline
\end{tabular}

$\mathrm{X}_{1}=\mathrm{pH} ; \mathrm{X}_{2}=$ Salinity $; \mathrm{X}_{3}=\mathrm{Cl}^{-} ; \mathrm{X}_{4}=\mathrm{SO}_{4}{ }^{2-} ; \mathrm{X}_{5}=\mathrm{HCO}_{3}{ }^{-} ; \mathrm{X}_{6}=\mathrm{CO}_{3}{ }^{2-} . \beta_{1}-\beta_{6}$ : Standardize regression coefficients corresponding $\mathrm{X}_{1}-\mathrm{X}_{6}$, the greater the absolute $\beta$ value, the stronger effect of the stress factor on every index. $R^{2}$ : the square of total correlation coefficient, $n=30$

Main stress factors of mixed salt-alkaline stresses are shown in Tab. 2. The results of stepwise regression analysis showed that there was a high linear correlation between each index and stress factors $(\mathrm{p}<0.001, \mathrm{Tab}$. 5). Among the absolute values of the regression coefficients in germination indexes, salinity $\left(\beta_{2}\right)$ was highest for the indexes, indicating that salinity was the dominant factor among the stress factors. While among the absolute values of the regression coefficients in radicle growth, $\mathrm{pH}$ was highest for the indexes, indicating that $\mathrm{pH}$ changed into the key factor on seedling establishment of $L$. chinensis.

\section{Discussion}

Seed germination is the initial and one of the most critical stages over the life cycle of plants. Lower water potential caused by salinity is the determining factor inhibiting seed germination under saline environment (Debez et al., 2004). Our results showed that high $\mathrm{pH}$ also significantly affected seeds germination. Germination percentage and rate were both affected by salinity, high $\mathrm{pH}$, and their interactions (Fig. 1, Tab. 3). Furthermore, $L$. chinensis seeds were more tolerant to only salt stress (A group) than mixed salt-alkaline stresses (B-F groups). This mainly due to that mixed salt-alkaline stresses not only had the same stress characteristics with salt stress, but also added the impact of high $\mathrm{pH}$ stress, so created more harmful effects. However, higher germination percentages were observed at lower salinity $(50 \mathrm{mM})$ in all the groups even though under higher $\mathrm{pH}$ treatments (D-F). This phenomenon indicated that germination was not inhibited by high $\mathrm{pH}$ when salinity concentration was low, which implied that high $\mathrm{pH}$ had a particular adjustment function on seeds at lower salinity. However, once salinity was higher, interactions of high $\mathrm{pH}$ and salinity might decrease seed germination, decompose seed structure and even result in seed death, the specific reason deserves further research. Most nongerminated halophyte seeds under high salinity environments will recover and germinate again after being transferred to distilled water (Song et al., 2006; Qu et al., 2008). Our result that recovery percentage in L. chinensis seeds showed increasing trends with salinity increment in all the treatment groups supports this phenomenon. This indicated an adaptive strategy of seed germination to high salinity stress, nongerminated seeds in a state of dormancy to escape from the rigorous environment (Debez et al., 2004). This phenomenon also indicated that high salinities only delayed germination process for most $L$. chinensis seeds but did not cause them lose viability. In addition, there are several possible causes that nongerminated seeds at higher salinity stress recovery well. First, the lower salinity conditions always suitable to $L$. chinensis seeds and most of them can germinate quickly in order to avoid the competition on seedling stage. Second, high salinity may enhance the priming effect on the nongerminated seeds and increase seed vigor and germination ability.

Early seedling growth is another critical stage for plants survive in salt-alkaline conditions. Our results showed that although shoot growth well at lower salinity stress, but radicle growth was greatly retarded especially at high $\mathrm{pH}$ groups, indicating that the radicle of $L$. chinensis was more sensitive to salinity and $\mathrm{pH}$ stresses. The results agree with $\mathrm{Li}$ (2010) for Spartina alterniflora. In addition, we found that although seedling lengths decreased with increasing salinity in each treatment group, the treatment with larger proportion of alkalinity resulted in lower shoot and root length. Similar results have also been reported for other plants (Li et al., 2010; Peng et al., 2008). The reason of this phenomenon may be due to the effects of high $\mathrm{pH}$ and its interactions with ions stress. The high- $\mathrm{pH}$ environment surrounding the radicles of $L$. chinensis especially with high salinity stress can cause ions imbalance, metabolic disorders, and also destroys the structure and function of root cells, results in lower elongations of the seedlings (Shi and Yin, 1993; Shi and Wang, 2005).

The deleterious effects of mixed salt-alkaline stresses are more complex than that of single salt or alkali stress due to the various salt components and proportions (Liu and Zhu, 1997; Shi et al., 2002). The stress characters of salt stress on plant contains osmotic and ionic effects, alkaline stress has the same characters with salt stress and exerts the high $\mathrm{pH}$ stress. However, when the neutral salts and alkali salts are mixed together, the negative influence on plant is much greater because of the interactions of salinity and high $\mathrm{pH}$ or various ions. For example, the stress on germination index and seedling growth index due to single salinity stress (from A1 to A5) or single high $\mathrm{pH}$ stress (A1, B1, C1, D1, E1 and F1) was smaller than that of salinity interacted with high $\mathrm{pH}$ (D4, D5, F4 and F5) (Figs. 1, 2). As a result, the reciprocal enhancement between salt and alkali stresses is characteristic of mixed salt-alkaline stress (Shi and Wang, 2005).

From the results of stepwise regression analysis among the stress factors, it was obvious that salinity was the dominant factor on germination stage under mixed saltalkaline stress conditions (Tab. 5). This mainly due to that salinity concentration in the soil determines the water potential, and water absorption is the critical factor for seed germination. Therefore, with increasing salinity, the potential surrounding the seed (difference potential inside and outside of the cell) gradually decreases, and it is difficult for seeds to absorb water under such circumstances, then higher salinity strongly affects germination percentage and germination rate of $L$. chinensis. However, we found $\mathrm{pH}$ 
changed into the dominant factor for radicle growth, and strongly affacted seedling establishment. This means that the mixed salt-alkaline stresses have different impacts on $L$. chinensis during germination and early seedling stage. Compared with seed germination, seedling stage is much more complex, radicle should absorb great number of nutrient elements and also maintain osmotic and ionic balance, and high $\mathrm{pH}$ can strongly inhibit ion uptake and disrupt ionic balance of plant cells. Therefore, once radicles break through the seed coat, and $\mathrm{pH}$ changes into the dominant factor for seedling establishment.

\section{Conclusion}

In summary, this study clearly showed that seed germination and seedling growth of $L$. chinensis were affected by salinity and high $\mathrm{pH}$ and their interactions. Nongerminated seeds germinated well after being transferred to distilled water, indicating that seeds of this species have recovery ability under salt-alkaline environment. Although radicle and shoot length were both inhibited by mixed salt-alkaline stresses, radicle growth was more sensitive to the stress. Salinity was the key stress factor for germination, while $\mathrm{pH}$ was the key stress factor for seedling establishment under mixed salt-alkaline stresses. The better understanding of the germination and seedling processes of $L$. chinensis should facilitate the effective utilization of this species under such complex environment.

\section{Acknowledgements}

The research was supported by the Fundamental Research Funds for the Central Universities (DL12BA32, 2572014EA04), and was also funded by National Natural Science Foundation of China $(31172259,31370432)$.

\section{References}

Debez A, Hamed BK, Grignon C, Abdelly C (2004). Salinity effects on germination, growth, and seed production of the halophyte Cakile maritime. Plant Soil 262:179-189.

Grutterman, Y (1993). Seed germination in desert plants. Berlin: Springer-Verlag 169-206.

Guo R, Shi LX, Yang YF (2009). Germination, growth, osmotic adjustment and ionic balance of wheat in response to saline and alkaline stresses. Soil Sci Plant Nutri 55:667-679.

Huang ZH, Zhu JM, Mu XJ, Lin JX (2002). Advances on the mechanism of low sexual reproductivity of Leymus chinensis. Grassland China 24:55-60.

Li R, Shi F, Fukuda K (2010). Interactive effects of salt and alkali stresses on seed germination, germination recovery, and seedling growth of a halophyte Spartina alterniflora (Poaceae). South African J Bot 76:380-387.

Lin JX, Wang JF, Li XY, Zhang YT, Xu QT, Mu CS (2011). Effects of saline and alkaline stresses in varying temperature regimes on seed germination of Leymus chinensis from the Songnen Grassland of China. Grass For Sci 66:578-584.
Liu GS, Qi DM (2004). Research progress on the biology of Leymus chinensis. Acta Prataculturae Sinica 13:6-11.

Liu J, Zhu JK (1997). Proline accumulation and salt-stressinduced gene expression in a salt-hypersensitive mutant of arabidopsis. Plant Physiol 114:591-596.

Munns R (2002). Comparative physiology of salt and water stress. Plant Cell Envir 25:239-250.

Peng YL, Gao ZW, Gao Y, Liu GF, Sheng LX, Wang DL (2008). Eco-physiological characteristics of alfalfa seedlings in response to various mixed salt-alkaline stresses. J Integr Plant Biol 50: 29-39.

Qu XX, Huang ZY, Baskin JM, Baskin CC (2008). Effect of temperature, light and salinity on seed germination and radicle growth of the geographically widespread halophyte shrub Halocnemum strobilaceum. Ann Bot 101:293-299.

Shi DC, Wang DL (2005). Effects of various salt-alkali mixed stresses on Aneurolepidium chinense (Trin.) Kitag. Plant Soil 271:15-26.

Shi DC, Yin LJ (1993). Difference between salt $(\mathrm{NaCl})$ and alkaline $\left(\mathrm{Na}_{2} \mathrm{CO}_{3}\right)$ stresses on Puccinellia tenuiflora (Griseb.) Scribn.et Merr. Plants. Acta Bot Sin 35:144-149.

Shi DC, Yin SJ, Yang GH, Zhao, KF (2002). Citric acid accumulation in an alkali-tolerant plant Puccinellia tenuiflora under alkaline stress. Acta Bot Sin 44:537-540.

Song J, Feng G, Zhang FS (2006). Salinity and temperature effects on germination for three salt resistant euhalophytes, Halostachys caspica, Kalidium foliatum and Halocnemum strobilaceum. Plant Soil 279:201-207.

Ungar IA (1991). Ecophysiology of vascular halophytes. Boca Raton: CRC Press 9-48.

Wang ZW, Li LH, Han XG, Dong M (2004). Do rhizome severing and shoot defoliation affect clonal growth of Leymus chinensis at ramet population level? Acta Oecologica 26:255260.

Yang CW, Chong J, Kim C, Li CY, Shi DC, Wang DL (2007). Osmotic Adjustment and ion balance traits of an alkali resistant halophyte Kochia sieversiana during adaptation to salt and alkali conditions. Plant Soil 294:263-276.

Yang CW, Shi DC, Wang DL (2008). Comparative effects of salt stress and alkali stress on growth, osmotic adjustment and ionic balance of an alkali-resistant halophyte Suaeda glauca (Bge.). Plant Growth Regul 56:179-190.

Zhang JT, Mu CS (2009). Effects of saline and alkaline stresses on the germination, growth, photosynthesis, ionic balance and anti-oxidant system in an alkali-tolerant leguminous forage Lathyrus quinquenervius. Soil Sci Plant Nutri 55:685-697.

Zhang JT, Mu CS, Wang DL, Wang JF, Chen GX (2009). Shoot population recruitment from a bud bank over two seasons of undisturbed growth of Leymus chinensis. Botany 87:12421249. 